\title{
THE EFFECTIVENESS OF A PROPOSED PROGRAM BASED ON BLENDED LEARNING TO DEVELOP ACHIEVEMENT IN WESTERN MUSIC GRAMMAR FOR STUDENTS OF THE FACULTY OF SPECIFIC EDUCATION
}

Nevin Mohamed Kamal El Din FATHY*

Department of Music Education, Faculty of Specific Education, Alexandria University, Egypt

\begin{abstract}
The grammar of Western music is one of the basic subjects that contribute to preparing the student in music, and then the teacher of music education in specialized colleges, and one of the requirements of this preparation is a good understanding and comprehension of the student and his ability to acquire the rules and theories of Western music and their application in the rest of the other subjects, so we find that it is necessary to pay attention. By dealing with the subject of Western music grammar in a variety of and innovative ways and methods of teaching in order to help students to understand and understand well the material Scientific.

Keywords

Effectiveness, Proposed Program, Blended Learning, Western Music, Grammar.
\end{abstract}

\section{Introduction :}

Technology has played a large role in the educational process, as the introduction of educational technology and information in the educational process is a vital and effective matter, due to its role in design, development, use, and evaluation. The intellectual and practical interaction between learners and the educational environment has become a feature of education and information technology. Education and information technology by educational institutions; In developed and developing countries, the development of education and the development of the individual and society is evidenced by the blended learning method, one of the modern educational methods that have proven effective in improving and developing the academic achievement of students, as it combines traditional education and e-learning.

Research problem :

Through the researcher's teaching to undergraduate students (the first year) of the subject of Western music grammar, the researcher found that there are some difficulties that students face in understanding and comprehending some of the lessons of the subject, namely (semantic reading, conversion signs, building and calculating distances, the fifth circle), and this means That there are deficiencies among students of the first band in the topics previously mentioned in the subject of Western music rules.

First, theoretical framework:

* Corresponding author: spedu@alexu.edu.eg 
1- Previous studies related to the research topic:

A- Studies concerned with the rules of Western music.

- A study entitled "The Effectiveness of a Program Based on Problem Solving Method in Developing Achievement in Western Music Grammar Subject for Students of the Faculty of Specific Education":

This study aimed at developing achievement in Western music grammar using the problemsolving method. The study followed the experimental method based on two equal groups of 20 students from the second group each, and the results showed the superiority of the experimental group that studied the problem-solving method over the control group that studied the method. It recommended the necessity of using modern educational methods, especially the problemsolving method in teaching Western music grammar subjects.

This study agreed with the current research in the goal of developing achievement in the subject of Western music grammar and differed with it in style and sample, and the researcher benefited from it in preparing the research procedures.

- A study entitled "Using the Cooperative Learning Method in Teaching Western Music Grammar Curriculum to Achieve Quality Music Education:"

This study aimed to develop achievement in the subject of Western music grammar using the cooperative learning method. The study followed the descriptive method with performing an exploratory experiment by implementing a lesson in Western music grammar where the research sample consisted of two equal groups of 16 students each from the first group, and the results showed superiority The experimental group that studied the problem-solving method on the control group that studied in the traditional way and recommended the necessity of training faculty members on how to use cooperative learning.

This study agreed with the current research in the goal of developing achievement in the subject of Western music grammar and differed with it in style and sample, and the researcher benefited from it in preparing the research procedures.

Theoretical concepts of research:

First: Blended Learning:

The teaching and learning processes in this era are no longer based on the traditional elements represented by both the teacher and the student, and knowledge has become not limited to the process of transferring information from the teacher to the student, but also on how the student receives this knowledge, and since the educational position is a communicative situation in which all interact The elements of communication represented by the sender, the receiver, the 
message and the medium, this vision is constantly evolving with the development of the means of communication between the two sides of the educational situation (the teacher and the learner).

As a result, the need for a new educational system appeared that combines the advantages of e-learning with the advantages of traditional education, which is called blended learning so that they share together in the completion of the educational process to the fullest, and blended learning is one of the teaching or learning formats in which e-learning is integrated, with traditional education within the framework of One, where e-learning tools, whether computerbased or network-based, are used in lessons, such as computer labs and smart classes, and the teacher meets the student face to face most of the time.

Among the most important advantages of blended learning:

- Shifting from a lecture method in education to student-centered education

- Increase interaction between student and teachers, student, student content, and student and external sources.

- Increasing access to information.

- The integrated training and collection of evaluation mechanisms for the student and the teacher.

- Achieving the best in terms of development cost and time required.

After the researcher examined some models for developing the design of educational systems in the literature on educational technology, the researcher adopted the model of Abd al-Latif al-Jazzar as an instructional design model for multimedia educational software.

The Abdul Latif Al-Jazzar model is a guiding model for designing and implementing the program.

A brief summary of the Abdul Latif Al-Jazzar model: This model was designed in 1990 AD, with the aim of helping teachers and researchers to develop lessons and educational units as an effective educational system. This model consists of five main stages, including sub-steps, and can be applied at the level of one lesson or at the unit level Study, and this model is in line with the systems methodology and scientific thinking steps.

The author of the model referred to the educational procedures that are taken into account when applying the model, which are many steps revolving around the educational reality, objectives, measures and tests that are used to judge the achievement of goals, teaching and teaching strategies, learning resources and the role of each of the learners and other human elements, as well as the structure of the initial building and the processes of amendment to it as a result Exploratory experimentation, evaluation and feedback processes that help in correlation and 
adjustment processes in all steps of the process of building the system

Second: Western rules of music:

They are the foundations and principles established by musicians to define the form of dealing with notes and rhythms with each other through a fixed and agreed upon musical system 2, and the musical notation includes lines, spaces, keys, tones, rhythms and strokes in addition to the formation of spaces, stairs, shrines, slashes, collages, photography and templates.

The study of the solvic reading and recording on the musical staff includes the identification of the names of lines and distances on the musical staff according to the multiple musical keys. In particular, the research topics include the key to the arrival of the soprano and the bass.

Third: Undergraduate student:

The students of the first year of the Music Education Division of the Faculty of Specific Education fall into the age group (17-20) years, which is called the late adolescence stage, and this stage has some characteristics, including:

1- Physical growth is characterized by an increase in weight and height for both sexes, and mature physical proportions are evident.

2- Mental development is characterized by the arrival of intelligence to the height of maturity and the acquisition of mental skills, logical, abstract and innovative thinking, problem solving, and increase in the ability to understand, achieve and mentally communicate with others.

3- Emotional development is characterized by a tendency towards emotional stability and a tendency towards idealism, and some personal emotions crystallize, such as self-care, appearance care, manner of speaking and understanding others

4- Social growth is characterized by the increase in social intelligence, the ability to act in social situations, the growth of aesthetic and social values, independence and sense of self.

\section{Results:}

- The researcher prepared a written test for the rules of Western music that was applied to the students of the first band, the experimental and control groups, and assigned to it (40) marks, consisting of three questions covering the topics of the program and measuring the students 'achievement at the level of remembering, understanding and application. At level 0. 01 between the mean scores of the experimental and control group students in favor of the experimental group in the post application of the Western music grammar test, using the T-test for independent groups.

- It is evident that the value of the "calculated $t$ is greater than the tabular $t \mathrm{t}$ " at the level of (0.11) for the benefit of the experimental group, which confirms the effectiveness of the 
combined learning method in developing achievement in the subject of Western music grammar, compared to what the control group did with its study in the used method. Thus, the validity of the research assumption is achieved that there are statistically significant differences at the level of glor $=0.01$ among the mean scores of the experimental group in the post application of the test.

- Thus, the positive results of the research in developing student achievement in the subject of Western music rules were in agreement with the positive results reached by the researcher Mal Farrag 2011, but they differed with the current research in the method. The positive results of the current research are also in agreement with the study of Debatrick Dyglow, MS / Elizabeth Andango, and Mister John Cattully 2008 on the effectiveness of using blended learning in the fields of music education.

\section{Recommendations:}

1- The researcher recommends using a built-in learning method in teaching the rules of Western music, with attention to diversification in teaching methods.

2- Conducting similar studies on student samples for other musical subjects.

3- The tendency to use modern educational methods in teaching, whether they are teaching strategies or technological innovations.

\section{References:}

1- Amira Sayed Farag: Solfege and Fundamentals of World Music, Part Two, Helwan University Press.

2- Ilham Harb Abu Al-Rish: The effectiveness of a program based on blended education in the achievement of tenth grade students in grammar and the direction towards it in Gaza "- Master Thesis - Islamic University - Gaza 2013

3- Enas Adel El-Sakka: Published research, the first international conference, Faculty of Music Education - Helwan University, 2010

4- Hamed Abdel Salam Zahran: The Psychology of Development - Childhood and Adolescence, The World of Books, Cairo, 1990.

5- Hassan Hussein Zeitoun: A New Vision in Learning - E-Learning Understanding, Issues, Application, and Evaluation - The Sound House for Education - Riyadh 2005.

6- Dio Boldb Van Dalen: Research Methods in Education and Psychology (translated by Muhammad Nabil and Salman Al-Khudary, Talaat Mansour) The Anglo-Egyptian Library, Cairo 1990

7- Suad Ali Hassanein: Teaching Hearing and Western Music Grammar, Part Two, Fifth Edition, Rotaprint House, Cairo 1992. 
8- Tariq Abdel Raouf Amer: Education and the Electronic School - Dar Al-Sahab and Distribution - Cairo 2007.

9- Abd Allah Ibrahim Al-Feki: Blended Learning - Instructional Design - Multimedia Creative Thinking, Faculty of Specific Education - Kafr El Sheikh University, Dar Al Thaqafa for Publishing and Distribution.

10- Abdul Latif Al-Jazzar "The Effectiveness of Using Multimedia Computer-assisted Education in Acquiring Some Levels of Learning Scientific Concepts According to the February Model for Conceptual Assessment" - Journal of Education - Scientific Journal of Educational, Psychological and Social Research - Faculty of Education, Al-Azhar University, 2002.

11- Fouad Abu Hatab and Amal Sadiq: Research Methods and Methods of Statistical Analysis in Psychological, Educational and Social Sciences, The Anglo-Egyptian Library, Cairo 1991. 12- Encyclopedia Britannica, INC, William, Benton, Publisher Chicago londan, torento , Geneva, Tokyo, Vol 22,1996

13- Dr. Beatrice A. Digolo, Miss Elizabeth A. Andang'o, Mr John Katuli , International Journal of Business and Social Science, Department of Music and Dance, Kenyatta University, 1st Regional Conference on e-Learning 2008.

14- Australian National Training Authority (2003) Blended Learning: learning new skills in blending. Sydney: Australian National Training Authority.

15- Hanaa Kamel Hassan AL-SAIDI, THE APPLICATION OF TOTAL QUALITY MANAGEMENT IN THE CURRICULUM AS AN INPUT TO ACHIEVE EDUCATIONAL EFFECTIVENESS (TEXTILE AND CARPET CURRICULUM MODEL), International Journal of Education and Learning Research, Vol. 2, No. 1, 2019, pp. 15-19.

Received: February 15, 2018

Accepted: April 20, 2018 